\title{
Konsep Arsitektur Tropis Modern pada Bangunan Kuliner Gading Festival Sedayu City
}

\author{
*Annisa Fiqri Jamila1, Anggana Fitri Satwikasari² \\ ${ }^{1,2}$ Arsitektur, Fakultas Teknik, Universitas Muhammadiyah Jakarta, Indonesia \\ fiqriannisa8@gmail.com
}

*Alamat korespondensi, Masuk: 13 Nov. 2020, Direvisi: 23 Des. 2020, Diterima: 29 Des. 2020

\begin{abstract}
ABSTRAK: Indonesia merupakan salah satu negara dengan iklim tropis. Hal-hal yang harus dipertimbangkan dalam mendesain bangunan di iklim tropis adalah curah hujan yang tinggi, radiasi matahari tinggi, suhu udara tinggi, kelembaban tinggi, dan kecepatan angin relatif rendah. Selain itu, Indonesia merupakan salah satu negara yang terkenal dengan bidang kulinernya, makanan dan minuman Indonesia banyak macamnya karena Indonesia terdiri dari berbagai macam adat dan suku. Indonesia juga kaya dengan bumbu-bumbu masaknya yang khas. Kuliner Indonesia juga menjadi sangat penting untuk menarik perhatian wisatawan. Perkembangan kegiatan kuliner di Indonesia dapat dikembangkan dalam satu wadah yaitu berupa bangunan pusat kuliner, tempat untuk berkumpulnya berbagai macam penyedia makanan dengan kegiatan memasak didalamnya dan menghasilkan olahan masakan menjadi makanan dan minuman. Pusat kuliner di Indonesia harus dapat menyesuaikan dengan iklim tropis, agar pengunjung merasakan kenyamanan ketika berkunjung dan menikmati makanan. Salah satu cara meningkatkan kenyamanan bagi pengunjung adalah menerapkan desain-desain yang responsif terhadap iklim tropis. Penelitian ini menggunakan metode deskriptif kualitatif. Penelitian ini dilakukan pada pusat kuliner modern yaitu Gading Festival Sedayu City Jakarta. Hasil dari penelitian ini, Gading festival sudah menerapkan prinsip-prinsip arsitektur tropis modern seperti menggunakan atap miring $35^{\circ}$ untuk menghindari kebocoran akibat curah hujan yang tinggi, tritisan yang panjang untuk menghindari radiasi matahari masuk ke dalam bangunan, cross ventilation pada bukaan bangunan membuat suhu udara sejuk, plafon yang tinggi membuat menyimpan banyak udara dibawahnya sehingga sirkulasi udara lancar dan kelembapan terjaga, vegetasi di sekitar bangunan dapat mengatur kecepatan angin yang lebih stabil.
\end{abstract}

Kata kunci: Arsitektur tropis, Modern, Pusat Kuliner, Gading Festival, Indonesia

\begin{abstract}
Indonesia is a country with a tropical climate. Things that must be considered in designing buildings in tropical climates are high rainfall, high solar radiation, high air temperature, high humidity, and relatively low wind speeds. In addition, Indonesia is one of the countries that is famous for its culinary fields, there are many kinds of Indonesian food and drinks because Indonesia consists of various kinds of customs and tribes. Indonesia is also rich in its distinctive cooking spices. Indonesian cuisine is also very important to attract tourists. The development of culinary activities in Indonesia can be developed in one container, namely in the form of a culinary center building, a place for gathering various kinds of food providers with cooking activities in them and producing processed dishes into food and beverages. The culinary center in Indonesia must be able to adapt to the tropical climate here, so that visitors feel comfortable when visiting and enjoying food. One way to increase the comfort for visitors is to implement designs that are responsive to tropical climates. This study used descriptive qualitative method. This research was conducted at a modern culinary center, namely Gading Festival Sedayu City Jakarta. The results of this research show that Gading Festival has applied the principles of modern tropical architecture, such as using a $35^{\circ}$ sloping roof to avoid leakage due to high rainfall, long dribbles to prevent solar radiation from entering the building, cross ventilation in building openings to make the air temperature cool. , the high ceiling keeps a lot of air underneath so that air circulation is smooth and humidity is maintained, the vegetation around the building can regulate a more stable wind speed.
\end{abstract}

Keywords: Tropical Architecture, Modern, Culinary Center, Gading Festival, Indonesian

\section{PENDAHULUAN}

Beberapa tahun belakang ini, perkembangan pusat kuliner di Indonesia semakin maju. Pusat kuliner adalah salah satu destinasi yang sering dikunjungi dan dicari oleh wisatawan maupun masyarakat sekitar. Bagi para orang-orang yang ingin membuka usaha, pusat kuliner adalah salah 
satu usaha yang peluangnya sangat besar. Berada di Indonesia salah satu negara beriklim tropis, membuat pusat kuliner harus menyesuaikan desaindesain yang responsif terhadap iklim tropis dengan seperti itu meningkatkan kenyamanan bagi para pengunjung yang datang.

Masih banyak pusat kuliner di Indonesia yang menggunakan pencahayaan dan penghawaan buatan, padahal anginnya sangat sejuk dan cahaya mataharinya pun melimpah. Dalam sebuah bangunan harus dapat menyesuaikan kondisi dan iklim di tempat tersebut. Kadang kala hujan yang sangat lebat, panas matahari yang sangat menyengat, dan hembusan angin yang sangat kencang. Salah satu yang dapat mencegah segala macam hal tersebut adalah dengan menerapkan arsitektur tropis. Arsitektur tropis adalah jenis gaya desain arsitektur yang mengadaptasi jawaban dan bentuk bangunan terhadap iklim tropis di suatu daerah tropis [1]. Pertimbangan desain bangunan di iklim tropis adalah curah hujan yang tinggi, radiasi matahari tinggi, suhu udara tinggi, kelembaban tinggi, dan kecepatan angin relatif rendah [2]. Desain bangunan tropis harus dapat menjawab semua permasalahan yang ada di iklim tropis.

Pada masa yang modern ini, Tropis dapat dipadukan dengan teknologi dan ilmu pengetahuan yang modern yang bersifat global untuk mewujudkan arsitektur yang lebih maju [3]. Perpaduan antara desain tropis dan modern adalah salah satu daya tarik tersendiri seperti penambahan arsitektur, interior, dan juga lanskapnya yang lebih modern tanpa menghilangkan tujuan awal dari arsitektur tropis. Tropis dapat dipadukan dengan teknologi dan ilmu pengetahuan yang modern yang bersifat global untuk mewujudkan arsitektur yang lebih maju. Pusat kuliner dengan menggabungkan tropis dan modern dapat membuat tampil beda. Fasad pada bangunan tropis yang hijau, asri, indah, dan interior yang modern dapat menjadi sesuatu daya tarik tersendiri bagi para pengunjung tanpa menghilangkan rasa kenyamanan berada di sana.

\section{STUDI PUSTAKA}

\section{Arsitektur Tropis}

Arsitektur tropis adalah jenis gaya desain arsitektur yang merupakan jawaban dan bentuk adaptasi bangunan terhadap kondisi iklim di suatu daerah tropis [4]. Setiap bangunan dengan arsitektur tropis, bangunan tersebut mudah diterangi oleh cahaya alami sepanjang hari yang masuk melalui bukaan pintu lebar, mempunyai jendela ventilasi silang di sekeliling bangunan, vegetasi pada sekitar bangunan serta skylight di beberapa sudut langitlangit atap [5]. Aliran udara akan menciptakan ruang segar, tidak kaku atau lembap, dan meminimalkan penggunaan kipas angin atau AC. Dampak dari konsep bangunan tropis yaitu orientasi bangunan, bukaan alami, material, suhu, vegetasi di sekitar bangunan juga memberikan hal positif yang sangat optimal untuk bangunan di iklim tropis.

Iklim tropis terletak di dekat garis khatulistiwa dan memiliki karakter khusus yang disebabkan oleh panas matahari yang tinggi, kelembaban dan curah hujan yang cukup tinggi, pergerakan angin, dan banyak pengaruh lainnya [6]. Pengaruhnya pada bangunan akan terasa apabila diantisipasi oleh desain arsitektur yang sesuai standar, sehingga manusia berasa nyaman ketika berada di dalam bangunan tropis. Selain itu, arsitektur tropis juga memperhatikan penggunaan material yang tahan terhadap kondisi iklim tropis, mampu menunjukkan ciri karakter material lokal (daerah tropis) yang lebih sesuai dan ramah lingkungan [7]. Bentuk bangunan juga harus disesuaikan sehingga dapat memberikan rasa nyaman dan aman bagi para pengguna.

\section{Klasifikasi Faktor Iklim Tropis}

Secara sederhana pengertian arsitektur tropis adalah suatu rancangan arsitektur yang mengarah pada pemecahan problematik iklim tropis. Sementara iklim tropis sendiri dicirikan oleh beberapa faktor iklim [8] seperti curah hujan tinggi sekitar 2000-3000 mm/tahun (Jakarta $+2000 \mathrm{~mm} / \mathrm{th}$ atau rata-rata $+160 \mathrm{~mm} /$ bulan), radiasi matahari relatif tinggi sekitar 1500 hingga 2500 $\mathrm{kWh} / \mathrm{m} 2 /$ tahun (Jakarta $+1800 \mathrm{kWh} / \mathrm{m}^{2} /$ tahun), suhu udara relatif tinggi untuk kota dan kawasan pantai atau dataran rendah (Jakarta antara $23^{\circ}$ hingga $33^{\circ} \mathrm{C}$ ), kelembaban tinggi (Jakarta antara 60 hingga $95 \%$ ), kecepatan angin relatif rendah (dalam kota Jakarta rata-rata di bawah $5 \mathrm{~m} / \mathrm{s}$ ).

\section{METODE PENELITIAN}

Penelitian ini dilakukan di Gading Festival Sedayu City menggunakan metode deskriptif kualitatif. Setiap aspek-aspek yang diteliti dijelaskan melalui deskripsi dan menegakkan faktafakta atau kebenaran-kebenaran dari suatu teori. Menurut Semiawan [9] metode penelitian kualitatif adalah metode penelitian yang digunakan untuk meneliti kondisi obyek alamiah, teknik pengumpulan data dilakukan dengan gabungan observasi, wawancara, dan dokumentasi.

\section{HASIL DAN PEMBAHASAN}

\section{Gading Festival Sedayu City}


Gading Festival Sedayu City, Jakarta Timur yang terletak di Jl. Sedayu Jalan Boulevard Raya No.1 Sedayu City Kecamatan Kelapa Gading, RT.8/RW.5, Rw. Terate, Kec. Cakung, Kota Jakarta Timur, Daerah Khusus Ibukota Jakarta. Pada April 2019, Sedayu City membuka lokasi pusat kuliner dan rekreasi baru bertajuk "Gading Festival" di daerah Kelapa Gading [10]. Gading Festival Sedayu City ini memiliki beberapa bangunan yang terdiri dari 3 bangunan kuliner dengan bentuk seperti tenda yang dibawahnya terdapat beberapa tenant, tenanttenant kecil yang berdiri sendiri tanpa bangunan yang berbentuk tenda, gedung serbaguna yang disewakan, dan bangunan marketing gallery.

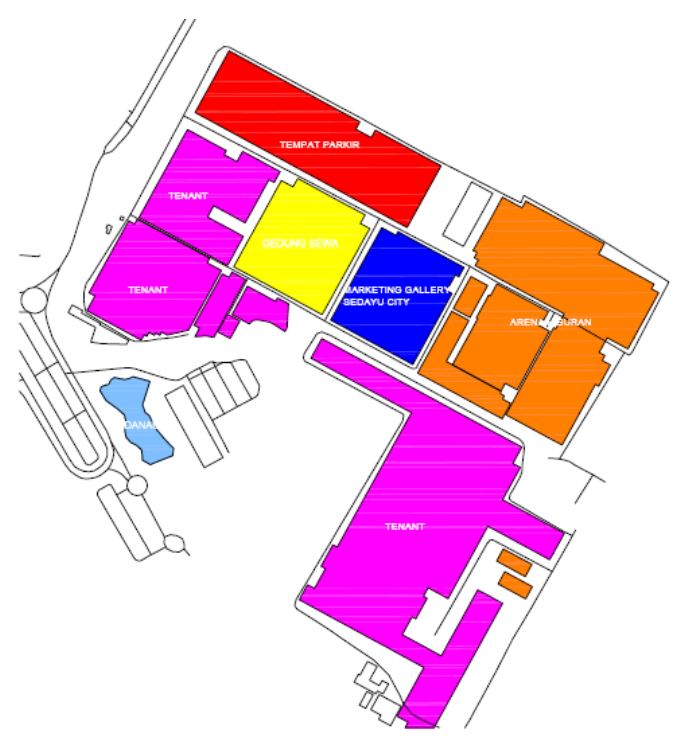

Gambar 1. Site plan Gading Festival Sedayu City

Pusat kuliner ini terdapat danau pada satu sisi. Danau dihiasi lampu-lampu berbentuk ubur-ubur atau tempat ini disebut jellyfish light show dan juga terdapat jembatan di atas danau.

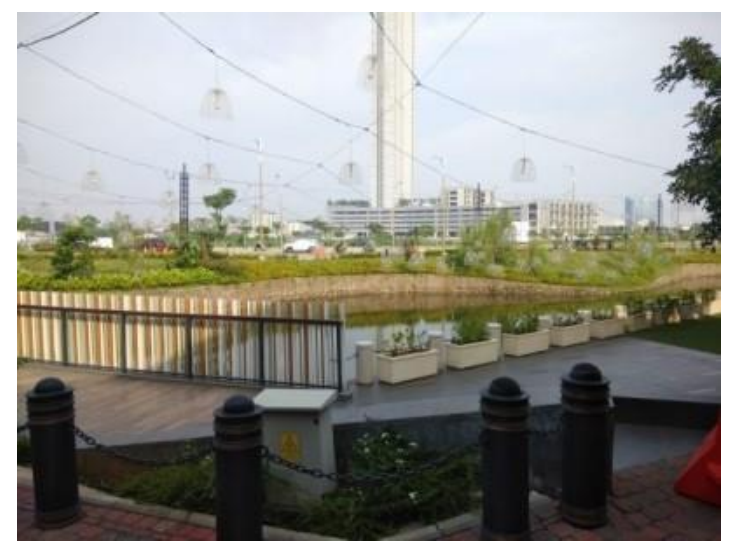

Gambar 2. Danau di Gading Festival Sedayu City
Gading Festival Sedayu City ini memiliki lebih dari 58-59 tenant makanan dan minuman dari kekinian maupun tradisional. Tenant adalah penyewa atau pihak yang menyewa suatu bagian dari properti. Macam-macam tempat yang sediakan ada yang hanya gerobak saja, ada yang berupa kedai-kedai kecil, dan ada yang hanya tenda dengan bahan kayu.
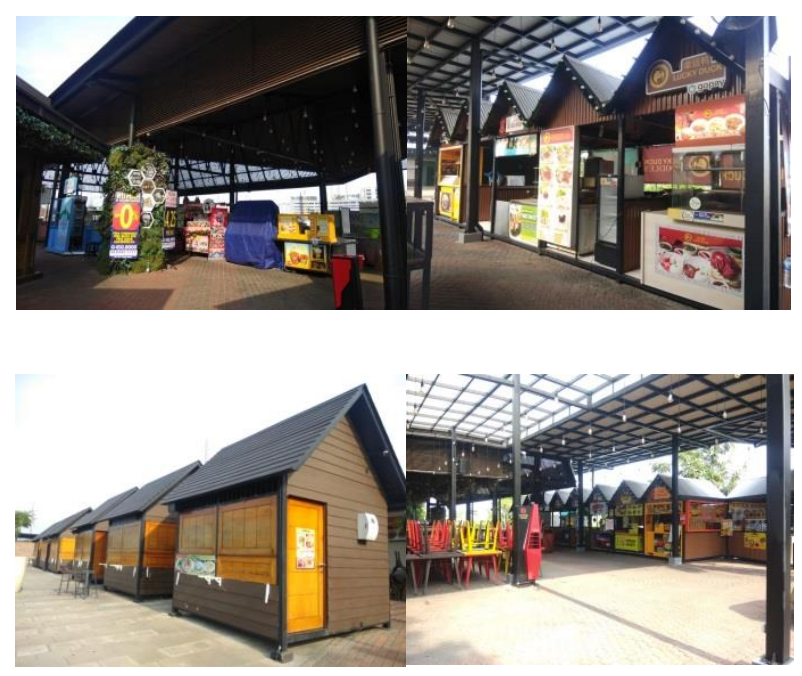

Gambar 3. Tenant di Gading Festival Sedayu City

\section{ATAP}

Penggunaan penutup atap pada daerah iklim tropis harus dapat mengurangi dan meredam panas matahari yang berlebih dengan baik. Gading festival menggunakan atap kayu yang mampu meredam panas matahari dengan baik dan memantulkan radiasi matahari.
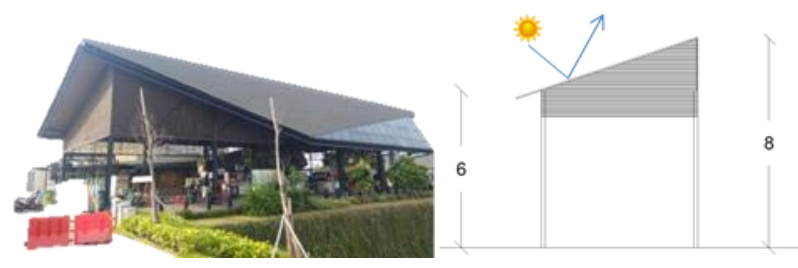

Gambar 4: Penutup Atap

Sumber : Dokumentasi Pribadi, 2020

Atap pada bangunan berkonsep arsitektur tropis umumnya berbentuk miring dengan kemiringan diatas $30^{\circ}$. Hal ini disebabkan bentuk atap seperti ini mampu membuat curah hujan yang tinggi di iklim tropis dapat mengalir lancar langsung ke tanah dan tidak tergenang pada bagian atas bangunan. Gading Festival menggunakan atap miring dengan kemiringan $30^{\circ}$. 


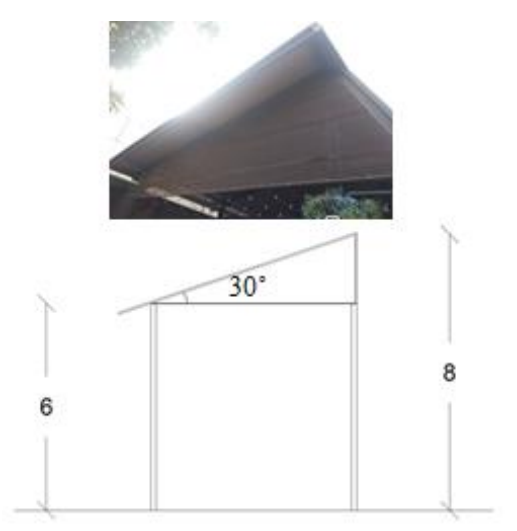

Gambar 5: Kemiringan Atap

Sumber : Dokumentasi Pribadi, 2020

\section{DINDING}

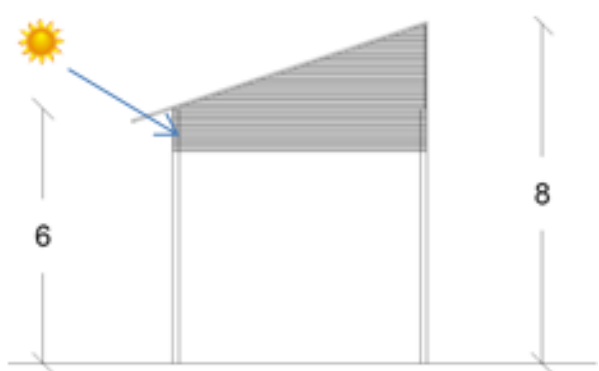

Gambar 6: Material Dinding

Sumber : Dokumentasi Pribadi, 2020

Bangunan tanpa dinding juga dapat menghalangi silau dan panas matahari masuk ke dalam bangunan. Penggunaan sun shading di bawah atap menjadi penghalang radiasi matahari masuk membuat panas matahari berkurang.

\section{TRITISAN}

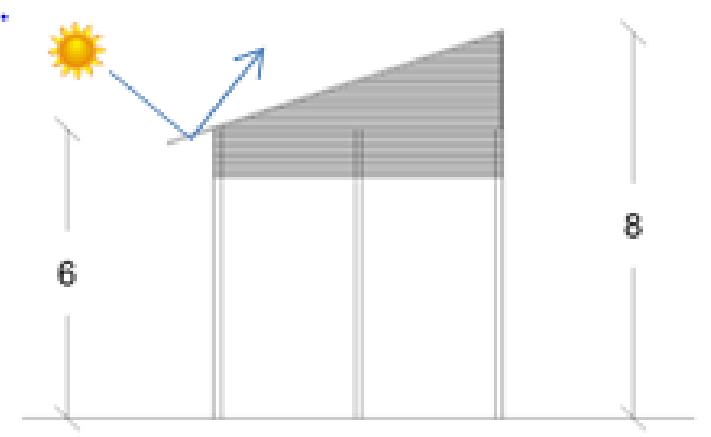

Gambar 7: Tritisan

Sumber : Dokumentasi Pribadi, 2020
Tritisan yang baik harus dapat memenuhi prinsip arsitektur tropis yaitu memasukkan cahaya matahari semaksimal mungkin agar memberikan kenyamanan di dalam bangunan dan menghalangi hujan yang lebat masuk langsung ke dalam bangunan [11]. Tritisan pada Gading Festival yang lebar dan melebihi badan bangunan membuat bagian bawah bangunan menjadi sejuk dan terhalang radiasi matahari. Lebar dari tritisan adalah 1 meter.

\section{VEGETASI}
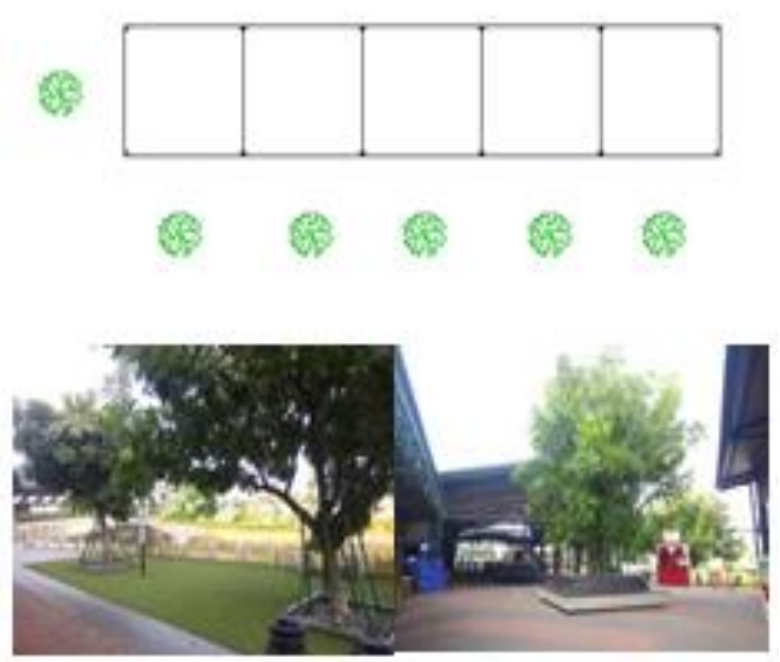

Gambar 8: Vegetasi

Sumber : Dokumentasi Pribadi, 2020

Vegetasi dapat mengurangi radiasi matahari ke dalam bangunan karena vegetasi dapat mengalangi dan menahan panas matahari. Area yang terbuka terdapat vegetasi yang terletak dekat bangunan akan membuat kelembaban menjadi tinggi sehingga tidak dapat merusak bahan bangunan. Area terbuka dengan vegetasi yang terletak dekat bangunan akan membuat suhu menjadi rendah dan membuat udara menjadi lebih sejuk. Vegetasi dapat mengatur kecepatan angin terhadap bangunan, kecepatan angin dapat menjadi stabil. Terdapat banyak pepohonan di sekitar bangunan ketika hujan turun dapat terserap pada tanah dan pohon. Terhalang dari panas matahari yang berlebih membuat lebih sejuk.

Vegetasi pada Gading Festival menggunakan pohon tanjung di sekitar bangunannya. Memiliki batang yang tidak terlalu besar dan daunnya tidak mudah rontok. Pohon ini biasanya digunakan untuk peneduh karena panas matahari dan polusi udara yang tinggi. 


\section{PLAFON}

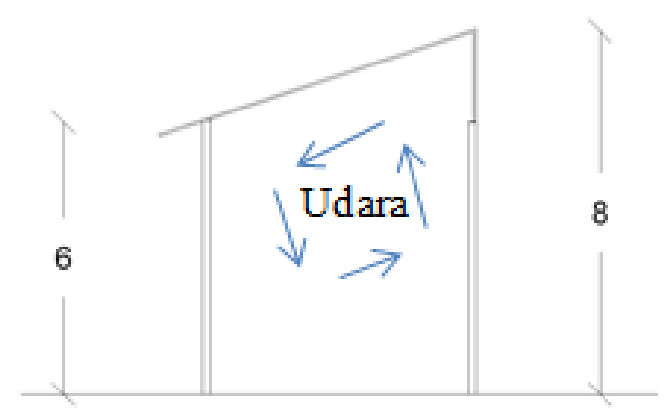

Gambar 9: Tinggi Plafon

Sumber : Dokumentasi Pribadi,2020

Gading Festival membuat ketinggian plafon sekitar 8 meter. Penggunaan plafon yang tinggi dapat mempertahankan udara dingin di area bawah sehingga bangunan menjadi lebih sejuk. Jadi, udara yang masuk bisa lebih banyak tersimpan di bawah atap maka sirkulasi udara lancar sehingga kelembaban terjaga (tidak tinggi dan tidak terlalu rendah).

\section{BUKAAN}

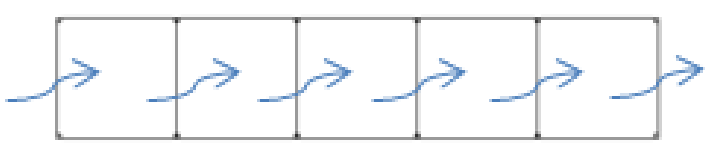

Gambar 10: Bukaan pada Gading Festival Sumber : Dokumentasi Pribadi, 2020

Gading Festival menggunakan bangunan naungan yaitu bangunan tanpa dinding hanya terdapat kolom dan atap saja. Sebab dari itu, memudahkan udara masuk sehingga suhu rendah dan menjadi lebih dingin.

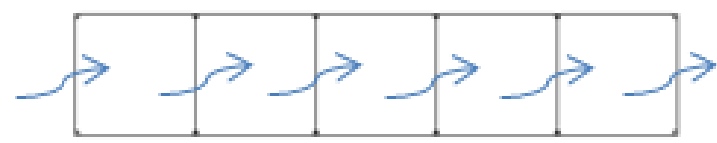

Gambar 11: Angin pada Bangunan Naungan Sumber : Dokumentasi Pribadi, 2020
Bangunan naungan memiliki kecepatan angin yang tinggi karena tidak menggunakan dinding hanya beratap saja. Angin yang masuk tidak terhalang dan membuat di bawahnya menjadi sepoisepoi. Bukaan dapat mempengaruhi ruang dalam bangunan, sebagai bentuk kenyamanan udara dan cahaya yang ada di dalam bangunan.

\section{MATERIAL}

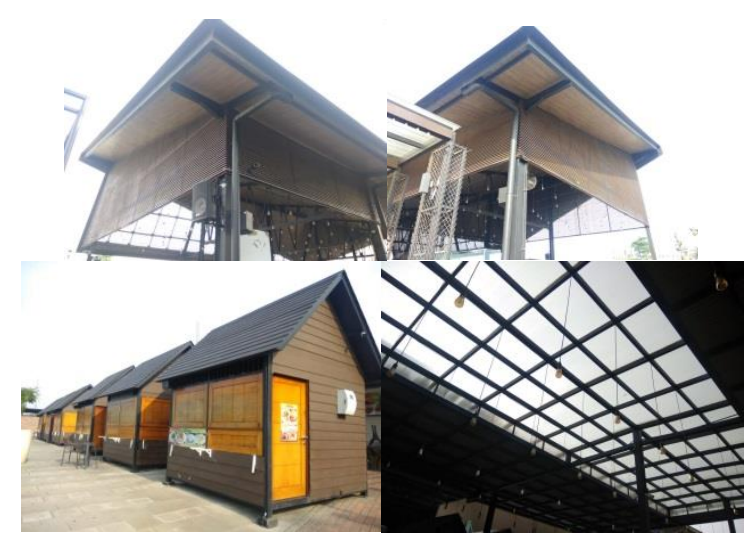

Gambar 12: Pemilihan Material Sumber : Dokumentasi Pribadi, 2020

Gading Festival dominasi menggunakan material kayu. Penggunaan kayu seperti pada atap, dinding, dan furnitur. Kelebihan dari material kayu adalah isolator alami pada suhu udara panas dan dingin sehingga memberikan kenyamanan. Selain itu memili sifat elastisitas sehingga tahan terhadap gempa.

\section{KESIMPULAN DAN SARAN}

Penerapan konsep arsitektur tropis modern pada Gading Festival Sedayu City memenuhi klasifikasi dari faktor-faktor iklim tropis. Gading Festival Sedayu City memenuhi kriteria dari ciri-ciri arsitektur tropis karena Gading Festival Sedayu City karena memiliki tritisan yang melebihi badan bangunan, bangunan berbentuk naungan dimana mudah mendapatkan penghawaan dan pencahayaan alami, penggunaan material yang dapat memantulkan radiasi matahari, terdapat vegetasi pada sekitar bangunan untuk membuat teduh, memiliki ketinggian atap yang cukup tinggi, memiliki kemiringan yang cukup curam.

\section{DAFTAR PUSTAKA}

[1] Purwanto L, and Hermawan S (2006) Pengaruh bentuk atap bangunan tradisional di jawa tengah untuk peningkatan kenyamanan termal bangunan. Jurnal Dimensi Arsitektur Vol. 34, No. 2: Hal. 154-160. 
[2] Samra B, and Imbardi I (2018) Penerapan Aspek Iklim Tropis pada Arsitektur Lokal Rumah Tradisional Melayu Studi Kasus di Desa Lalang Siak Sri Indrapura. JURNAL TEKNIK Vol. 12, No. 1.

[3] Hardiman G (2012) Pertimbangan iklim tropis lembab dalam konsep arsitektur bangunan modern. JURNAL ARSITEKTUR Vol. 2, No. 2.

[4] Karyono TH (2016) Arsitektur Tropis dan Bangunan Hemat Energi. Jurnal Kalang, Jurusan Teknik Arsitektur, Universitas Tarumanagara Vol. 1, No. 1.

[5] Prasidya AA, and Citraningrum S (2019) Evaluasi Konsep Tanggap Iklim Tropis pada Cafe Mezzanine di Kota Yogyakarta. Jurnal Mahasiswa Jurusan Arsitektur Vol. 7, No. 2.

[6] Willyanto E (2016) PENGARUH DESAIN ARSITEKTURAL TERHADAP KENYAMANAN TERMAL BANGUNAN IKLIM TROPIS LEMBAB. Jurnal Arsitektur Universitas Tarumanegara.

[7] Karyono TH (2011) Bangunan Hemat Energi: Strategi Penghematan Energi Bangunan di Kawasan Sub Tropis dan Tropis Basah., Dipresentasikan pada Seminar Bangunan Hemat Energi, Balai Besar Teknologi Energi (B2TE).

[8] Karyono TH. (2000) Mendefinisikan kembali Arsitektur tropis di Indonesia. 7-8 p.

[9] Semiawan CR. (2010) Metode penelitian kualitatif. Grasindo.

[10] Oktavia M. (2019). Gading Festival: Pusat Kuliner dan Rekreasi oleh Sedayu City. https://ultimagz.com/jalanjalan/gading-festival-pusat-kuliner-dan-rekreasi-oleh-sedayu-city/, diakses pada: 12 April 2020.

[11] Winandari MIR, Iskandar J, and Saputra E (2017) Pengaruh Iklim Terhadap Elemen Pelindung Selubung Bangunan di Rusunawa Tambora Jakarta. Dipresentasikan pada Prosiding Seminar Nasional Cendekiawan ke 3, Vol. Buku 2. 